\title{
The implication of organizational culture for building organizational identity strategy (Case study of PPID Ministry of Finance)
}

Reinaldy Ferdiansyah

Magister of Communication Science, Faculty of Social and Political Science, Sebelas Maret University, Surakarta, Indonesia

Email: reinaldy.ferdiansyah@student.uns.ac.id

Andre Noevi Rahmanto

Departement of Communication Science, Faculty of Social and Political Science, Sebelas Maret University, Surakarta, Indonesia

Email: andreyuda@gmail.com

Yulius Slamet

Departement of Sociology, Faculty of Social and Political Science,

Sebelas Maret University, Surakarta, Indonesia

Email:yuliusslamet48@gmail.com

\begin{abstract}
This article was made based on the changing needs of the community for information in the era of information and communication technology. To be able to communicate policies in the field of public information disclosure, the government must be able to realize transparently, effectively, efficiently and accountably. The communication process must be supported by a good and reliable organizational identity. This research was conducted to see the
\end{abstract}


implications of how organizational culture changes in the digital era in the Ministry of Finance's public information service process since 2018. The organizational communication process is used as a liaison for the creation of good relations between organizations and the public. This study uses descriptive analytic research methods with results that explain that organizational culture is important in supporting changes in PPID Ministry of Finance's (PPID MoF) public information service activities in the digital age. The implication can be seen that changes in the PPID MoF organizational identity through the use of social media will depend on the organization's strategy and organizational cultural activities. Furthermore, it is expected that the use of social media can be used as a way to educate and increase public participation in the field of public information services.

Keywords: Identity Development, Organization Communication, Communication Strategi, Social Media, Organization Culture.

\section{INTRODUCTION}

The concept of organizational governance that is applied based on the principles of fairness, openness, and a sense of responsibility is the implementation of good governance processes that are used to achieve organizational goals (Sriwijayanti, 2019). Improving the quality of human resources needs to be carried out in a fully planned, directed and sustainable manner. This is the basis for improving the performance of government resources in order to foster professionalism at work (Trisnawati \& Wiratmaja, 2018). Government transparency can be implemented by opening up to the rights of the community, namely in terms of obtaining correct, honest and non-discriminatory information (Nasution, 2018). Two main resources in the PR Industry, namely the importance of organizations having management and employees as production services, and information and communication as services to the external and internal public (Nguru \& Ibrahim, 2018).

In order to provide Public Information services, the implementation of Law Number 14 of 2008 in the Ministry of Finance is based on the Decree of the Minister of Finance (Finance, 2019b). The Head of the Communication and Information Services Bureau is appointed as PPID of the Ministry of Finance who performs the task of providing public information services to the Ministry of Finance and is responsible for storing, documenting, providing, 
and/or providing public information services within the Ministry of Finance (Finance, 2019a).

PPID MoF identity development in realizing targeted public information services must be strategically planned for identity building and organizational branding in gaining public trust. The interpretation of identity is based on various kinds of social identity theories, where the theory examines how people identify themselves by referring to other social groups (Tench \& Yeomans, 2017). The public prioritizes the best service by looking at the image of the company or organization. This will affect the trust and use of company services by the public (Khopipah \& Turistiati, 2019).

Managerial processes and internal communication have an important role to play in strengthening the organization. Organizations that do not have a strong identity will struggle to build and maintain a reputation in the long term (Maier, 2016). Recognition of the identity of an organization has an important role in seeing the level of society's need for that organization. The concept of identity refers to the relationship to external stakeholders that an organization expresses and categorizes itself. With the emergence of organizational communication and strategic communication that was put forward by Alvesson in 1990, the recent focus on the ideational dimension of the organization has an important role in the process of building image, reputation and identity (Tench \& Yeomans, 2017).

The fast evolution of the internet has offered many new opportunities to search for information and communicate without boundaries over the last few decades. Starting with the modernization paradigm of academics that supports the transfer of technology to society (Ibrahim \& Tijjani, 2019), currently technology is developing and it is possible to express feelings and thoughts through social media (Tsimonis \& Dimitriadis, 2014). The migration of a large number of Internet users to social media channels can affect strategic communication as well as speed up the communication process. In reaching large numbers of people, companies try to change their views either positively or negatively when social media content becomes viral in society (Plowman, 2013).

Social media can be used by companies to access millions of people. Tsimonis \& Dimitriadis (2014) explain that the use of social media by a large number of people can be utilized by companies, because social media networks can help provide information about the company and make people familiar with the company, and can create brand awareness. Currently, many professionals 
in the field of communication use social media because of its ability to reach the wider community, generate viral information dissemination, and get the public involved (Macnamara, 2010), and enable active community participation (Kreiss, Meadows, \& Remensperger, 2015).

Organizational communicators hope that by using social media, they can meet the needs of external stakeholders which increasingly increase demands for organizational transparency, thus maintaining public trust in the organization (Uzunoglu \& Onat, 2012). Communication managers must have the right capacity in using technology, especially professionals who are designated as managers of communications in the government (Putra, 2017). A strategic plan is needed by organizations to be consistent in all aspects of communication, including when measuring trends before, during, and after a campaign to be able to show the impact of social media on the organization (Plowman \& Wilson, 2018).

Several previous studies discussed more about the role of practitioners in carrying out communication strategies through social media and building organizational identity through social media. As has been done by Kenneth D. Plowman \& Christopher Wilson (2018) which shows that practitioners are involved in the development of social media strategy and tactical implementation, they have not seen that their involvement is largely related to their organizational strategy from tactical social media activities. In addition, Marius Badea (2014) explains social media strategy and some organizational constraints and risks in the use of modern communication methods. Furthermore, Dursun Bingöl et al. (2013) talked about the need for an evaluation of the value of organizational culture which requires the development of new strategies to get a better understanding of the corporate organizational identity which is a limitation of their research.

In this study, there are limitations related to the value of organizational culture in previous research and the interests of the PPID MoF in realizing good state administration in public information disclosure, researchers feel the need to conduct research related to the implications of organizational culture on the development of the PPID MoF organizational identity in order to increase active participation and trust. public. Analysis related to the relationship of organizational culture activities and the formation of the PPID MoF identity through social media is important to know considering that the PPID MoF is one of the public bodies that has received the best predicate in the field of public information disclosure since 2014. 


\section{LITERATURE REVIEW}

\section{Organizational Identity}

The concepts of image, reputation and identity have conquered the minds and souls of many executives or communications managers over the past two decades. This concept not only affects the business world, public organizations are also affected (Tench \& Yeomans, 2017). In categorizing the role of the public, organizational identity can be influenced by the identification process of problems, solutions, and the relationship between the focus of the organization and certain audiences (Jensen et al., 2012; Glynn \& Navis, 2013; Paolella \& Durand, 2016).

Organizational identity has a strong influence on organizational performance in building organizational image. Organizational identity is needed as a measure of organizational personality in the view of society. Organizational identity is not only in the form of a company brand, but includes work ethics and policies which are specific characteristics inherent in the organization and are associated with the relationship between image and organizational culture (Prasetyo \& Himam, 2013).

Organizational identity theory explains that organizational identity works independently and can be used to see the combined benefits of organizational theory practice (Mujib, 2017). Furthermore, Maier uses corporate communication theory described by Van Riel and Fombrun, which theorizes that organizations without a strong sense of identity striving to develop a coherent brand will be impossible to build and maintain a strong reputation in the long term (Maier, 2016).

Implementing the concept of organizational identity in an organization is not easy to do. The concept of organizational identity focuses on patterns of meaning and reason among members of an organization that lead to general values that exist in the organization, identification of the organization, and a sense of belonging (Cornelissen, 2014). Organizational identity will depend on the meaning given to it by organizational members, this has made previous researchers understand that organizational identity is seen from a social constructionist perspective (Mujib, 2017; He \& Brown, 2013).

Based on this, researchers argue that organizational identity has an influence on the development of organizational image. Thus, people's view 
of an organization will be influenced by the personality of the organization which will be linked to the organizational culture. Identity needs to be built and maintained by focusing on the organization's vision and mission, so that identity development must start from the organizational identification stage.

\section{Communication Strategic Management}

The relationship between Public Relations (PR) and communication strategy is about the organization and its environment. The corporate communication strategy is adaptive, when the strategy involves a process to balance the mission and vision of the organization with regard to external environmental conditions, it can encourage the organization to make strategy formation (Cornelissen, 2011).

Communication strategies are often planned in support of organizational actions to achieve the desired results. The communication strategy is defined as a "communicative construct" because it comes from the interaction pattern between the communicant's responses, context, and discursive patterns (King, 2009). Christensen \& Cornelissen (2011) and Olivant (2016) add that the company's communication strategy includes the organization and its environment. Meanwhile, strategic communication management aims to focus on results (Lukaszewski, 2013). Strategic communication that focuses on measurable goals must always be monitored with an evaluation which in the process consists of themes, messages, and products (Plowman, 2013).

In Strategic Communication Planning Theory, Van Ruler (2018) strategic communication is used to build organizational strategy. The models used in strategic communication planning and public relations planning will be mostly the same (Smith, 2013). Meanwhile, the concept used for strategic campaigns is a different process and there is no general theory that can be used to explain the strategic campaign process and predict the results (Werder, 2015).

Organizational evaluation is very important for strategic communication planning in measuring the level of organizational change with respect to public expectations. Atkin \& Rice (2012) explained that evaluation allows organizations to adapt to campaign strategies based on continuous assessment. Plowman (2016) and Olivant (2016) agree on the delineation between communication strategy and tactics. The one-way transitional communication model can be used for a long-term strategy by involving the public (Macnamara $\&$ Zerfass, 2012). Public communications that are interconnected must be 
fluid, volatile, and participatory (Murphy, 2011). Communication strategy is an effort to disseminate messages or information in helping organizations map the situation to the target target. Cangara (2013) explains that the ACADA planning model focuses on the fact-finding process at the initial stage and program implementation at the next stage.

In this connection, a relevant perspective in supporting the development of organizational identity is to carry out a communication strategy. One of the communication planning models to see the relationship between supporting components and make projections that can affect the implementation of a communication strategy is ACADA (Cangara, 2013). For this reason, researchers believe that the communication strategy process is important for organizations in the process of developing organizational identity.

\section{Communication and Organizational Culture}

When we communicate with one another, we create structures, patterns of rules and norms that range from large social and cultural institutions to smaller individual relationships. Structuration Theory has often been applied to this research on organizational communication because of the importance of structures and systems for organizing (Littlejohn et al., 2017).

Besides organizational communication, organizational culture is important in supporting the organizational development process. Organizational culture as an organizational learning material in finding solutions to external problems and integration by looking at the basic common assumptions that the group learns when solving problems (Schein, 2010). Organizational culture is one of the most popular approaches to scientific research and teaching about organizations. The organizational culture movement has become very broad, touching almost all aspects of organizational life (Littlejohn et al., 2017). Several important characteristics related to organizational culture such as the behavior of organizational members, reflected norms, dominant values, organizational philosophy on how to treat stakeholders, firm rules, and organizational climate that sees how employees interact (Ojo, 2010).

Furthermore, Schein (2010) states that there are 3 (three) cultural levels that are important for the development of organizational culture. The first level of culture is artifacts, which are cultural products that are visible in the form of phenomena that can be felt, heard, and seen when we are in a new group environment. The visible artifacts from the organization include architecture, language, and technology and product. Second, beliefs and values, which are 
goals, values, and rationality to be used as a guide or evaluation of a phenomenon and simplification of values to focus on organizational actions and goals. The last is basic assumptions, implicit assumptions about how the organization acts that emphasize how members of the organization think, see, and feel and can influence the behavior of members and the organization as a whole.

Organizational culture becomes important in the process of planning communication strategies and building organizational identity. Based on the above discussion, researchers assume that organizational culture will see the behavior of organizational members and be associated with organizational rules. Changes in organizational culture will determine the organizational climate in realizing an organizational identity development strategy.

\section{New Media}

A terminology used to describe the convergence process of digital communication technology connected to a network can be said as new media. The existence of new media will change the existing ecosystem, but it cannot be said as a substitute. New media is generally additive, this is one of the laws of communication technology (Naughton, 2012).

With the existence of new media, in this case the internet, offers a new way for the public to obtain public information on Public Bodies. Technology plays a major role in narrowing time, space and distance so that they are connected to each other in cyber space (Jati, 2016). The development of new media provides opportunities for organizations to engage in conversations with stakeholders or the general public in an interactive manner (Cornelissen, 2011).

Quick response to various requests or needs of the public is something that must be owned by the Government, because it is a demand for the needs of modern society. In other words, the government must be able to carry out all service processes needed by the community in whatever form it must be provided properly, quickly and cheaply. The public does not need to see how the government process organizes itself, for that the government must be able to apply information and communication technology in every public service delivery (Rahmawati, 2011). 


\section{Social Media Management}

Social Construction of Technology (SCoT) is a new media theory which is mostly seen and used as an approach to the history of the study of new technology. ScoT sees that the involvement of actors and groups has the potential to form all technologies where social action must be maintained in the process of communication and interaction through the use of social media (Octavianto, 2014). Meanwhile, Theory of Connective Action highlights the social media mechanism through the use of hashtags which are used as narratives that are built collectively in building brand awareness, interaction processes, and identity (Blaszka et al., 2012); Hambrick \& Pegoraro (2014); Clark (2016).

According to Wright \& Hinson (2015), PR practitioners feel that PR should be responsible for monitoring and managing social media communications and those that appear in organizations. Social media planning correlates with social media leadership and influence (Sweetser \& Kelleher, 2011). However, most PR practitioners do not have a real idea of what is working and what is not in their social and digital programs but they must develop strategic communication through social media (Theaker, 2016).

The development of social media is very explosive. The penetration of social media can quickly affect the community and use corporate branding and marketing strategies, although it has not been used by most companies (Dickey \& Lewis, 2010; Gallaugher \& Ransbotham, 2010; Kaplan \& Haenlein, 2010). Brand communication through social media is defined as the process of distributing corporate identity through social media.

The large number of people who access social media can be used by companies to use social media to build relationships with millions of people. Companies can use social media to socialize about the organization and create relationships with the community. This can foster brand awareness in the community (Tsimonis \& Dimitriadis, 2014). Thus, according to researchers, it is important to carry out social media management in this digital era to support communication strategies in building organizational identity. Social media management is used to integrate changes from the information technology side to organizational cultural habits through clear rules and standards. The use of hashtags can be used as a tool to generate discourse in society regarding organizational identity. 
Informasi, Vol. 51. No. 1. (2021), 1-26

\section{METHODS}

\section{Data Collection}

Secondary data and primary data were specifically collected by researchers for research purposes (Saunders et al., 2016). Data collection techniques vary through six sources of evidence such as documentation, archives, direct observation, participant observation, physical artifacts, and interviews (Yin, 2018).

Researchers used primary data obtained through a semi-structured interview and observation process. Semi-structured interviews are used to understand the relationship between variables when collecting empirical data and answering research questions (Saunders et al., 2016). In this study, interviews were conducted on three levels of positions in the organization, namely the Head of the Data Management and Information Services Management Section, the Head of the Sub-Section for Data Management and Information Dispute Handling (Head of PDPSI), and the Staff at the PDPSI Sub-Section as the PPID MoF social media admin. The selection of respondents was based on the implementation of PPID duties and functions of the Ministry of Finance by Data Management Section. Meanwhile, observations are made by looking at work patterns and being involved in the PPID MoF work process.

Meanwhile, to obtain secondary data, researchers conducted an analysis of books, journals, related official documents, Ministry of Finance website, PPID MoF social media, and seminars related to qualitative content analysis methods, which systematically illustrate the importance of context in determining meaning (Flick, 2013; Krippendorff, 2018).

\section{Data Analysis}

After collecting empirical data, data analysis was carried out to answer research questions according to research needs. The use of descriptive analytic research methods in this study aims to see the organizational design of the categories found and the relationships that arise (Kusuma, 2013). Furthermore, research can provide depth and understanding of existing problems by revealing informants perspectives (Lindlof \& Taylor, 2017).

\section{Research Quality}

The quality of all parts of the research must be ensured and can be achieved by validity, reliability, and research ethics (Yin, 2018). In addition, data 
validity is obtained using four criteria, namely (1) credibility, (2) transferability, (3) dependability, and (4) confirmability. The triangulation of data used in this study is source triangulation which has been carried out by conducting a semi-structured interview process, while the researchers conducted validity and reliability tests based on credibility criteria which include the adequacy of materials and the data triangulation process (Perdana et al., 2016).

\section{RESULTS AND DISCUSSION}

\section{PPID MoF identity in the Public Information Service Process}

Providing information needed by the public is one of the tasks that must be carried out by the Bureau of Communication and Information Services. This task is a form of transparency of government performance, as well as optimizing public oversight.

In 2018, the PPID MoF took the initiative to carry out a survey of the PPID MoF information services in 2017 as an effort to improve the PPID MoF information services. The survey generates information regarding preferences, understanding, and satisfaction levels of information applicants using the PPID MoF information services. This activity is in line with the process of categorizing the role of the public wherein the identification of the relationship between the organization and certain audiences is carried out (Jensen et al., 2012; Glynn \& Navis, 2013; Paolella \& Durand, 2016).

The results are used as input for the development or improvement of the PPID MoF services. To improve the performance of providing this information PPID MoF is used survey to see public satisfaction. This survey targeted users of the PPID MoF information service during 2017. The survey was conducted through 1017 email users with details of 770 emails being read, 455 opening the survey link, and 414 respondents filling in the survey link (KLI, 2017).

Two important steps used as the basis for discussing the PPID MoF communication strategy in building identity are public habits and understanding. This was done to assess the organization from the functional and social constructionist side as described by He \& Brown (2013). First step is to measure the habits, at this stage the background and reasons for the respondents using PPID information services are taken. The use of information technology in the form of websites, applications and social media seems to be more attractive to respondents. Second step is to measure the level of understanding, not only the 
habit of using information services, the respondents are also confronted with knowledge about PPID information services. This can see the gap or similarity between understanding and the level of respondent satisfaction.

Based on the survey results, the level of public habits and understanding can be used as benchmarks for the PPID MoF to see the extent of public participation in the Ministry of Finance's public information services. The use of the PPID MoF information services based on the survey results resulted in a very good public perception. In percentage terms, most of the public who have submitted requests for public information think that the PPID MoF is always responding to the request (35.7\%), the information provided by the PPID MoF is accurate (30.4\%), and the ease of access to information services (18.6\%). These results prove that the influence of organizational identity includes the PPID MoF work ethic and policies in it, according to research conducted by Prasetyo \& Himam (2013)

In this regard, PPID MoF tries to reach the level of public understanding of the Ministry of Finance's public information services. One example of the development of the survey results is the use of social media to provide education to the public on PPID and public information disclosure within the Ministry of Finance. To accommodate these educational activities, the PPID MoF uses various social media channels such as Twitter, Instragram, Facebook, and Youtube.

As a form of a follow-up to the PPID information service satisfaction survey in 2017, the PPID MoF began discussing the communication strategy planning process to carry out some of the suggestions generated from the survey. This is part of the PPID MoF commitment to always innovate and improve public information services in order to achieve the goal of information disclosure within the Ministry of Finance. Thus, PPID MoF feels organizations without a strong sense of identity must struggle to build and maintain a reputation as explained by (Maier, 2016).

\section{PPID MoF Communication Strategy Management}

The process of planning a communication strategy to build the PPID MoF identity through the use of social media has been carried out since semester 2 of 2018. Thus, the PPID MoF has made efforts to conduct public communication that is fluid, volatile, and participatory as explained Murphy (2011).

The Head of the Data Management and Information Service Management Section is assisted by the Head of the Subdivision of Data Management and 
Information Dispute Handling along with several PDPSI Subdivision staff to analyze to make a communication planning strategy. The communication strategy is carried out in order to build the PPID MoF identity so that it can reach the wider community in accordance with the obligations in the Law on Public Information Openness and in order to build effective communication with the community. It can be seen that the communication strategy carried out is in accordance with the opinion of King (2009) which states that all come from interaction patterns. Namely the relationship between context, communicant responses and discursive patterns.

In this case, the researcher explains the process by using the ACADA communication planning model which consists of Assessment, Communication and Analysis, Design, and Action (Cangara, 2013) on the communication strategy that will be created. This is in line with the effort to map the situation to the target targets to find initial facts and implement further programs. The results of the analysis are based on the result of interview, observation, and triangulation of data which found a finding by ACADA analysis process.

First step in the communication planning process is Assessment, namely by describing the description of the problems that occur. This analysis is including, a) The identity of the PPID MoF is not yet known to the wider community, although in the past 6 years the PPID MoF has always received the title of the best Public Agency in the field of public information services in the Ministry category; b) The development of the PPID MoF identity is very much needed in realizing public information services that are right on target and can reach the community, according to the original purpose of the formation of the Central Information Commiton (KIP) Law. c) Every year the PPID MoF always monitors and evaluates public information services. In this case, innovation will continue to be made to improve the quality of the Ministry of Finance's public information services.

Second process is communication and analysis, It is a mapping of the availability of existing communication infrastructure, developing communication objectives, and implementing evaluation indicators that include, a) Ministry of Finance already has a strong image when compared to the PPID MoF. With the Ministry of Finance's website and supported by the PPID MoF website, it will expand the information and communication network to the Public; b) To improve the quality of public information services, one of the goals that the PPID MoF should do is to facilitate the process of delivering information and communication with the public; c) The use of hashtags is a trend used 
by netizens in creating a discourse through social media; and d) Information related to state finances and assets is an important issue that develops in the community if it is not well informed, it must be communicated in order to create a transparent goverment.

Design is the third process which steps in determining and establishing a communication strategy include, a) Strategy of forming its identity, the PPID MoF hopes that the message to be conveyed is a message that reflects that the PPID MoF is part of the Public, which is entirely based on experience, knowledge and understanding of the real facts. The first step taken by the PPID MoF is to formulate a communication plan and strategy with all public information service officers on how to campaign identity on social media; b) Process of submitting the introduction of the PPID MoF identity will be carried out through several social media platforms according to the trend of digital communication technology in Indonesia; c) By utilizing social media to support the management of public information disclosure, there has been a change in the work culture of employees at the PPID MoF.

The last process is Action or implementation carried out, which including the PPID MoF social media account creation, the use of the hashtag \#temantransparent as a form of building PPID MoF identity, undertake a special strategy to campaign to the public through social media, and process of monitoring and evaluating the implementation of the PPID MoF activities through social media.

\section{Social Media Management and PPID MoF Work Culture}

Cornelissen (2011), Rahmawati (2011), and Naughton (2012) state that the involvement of organizations to convey messages to the public interactively and the provision of good, fast, and inexpensive service processes to society can be seen as a process of changing the ecosystem or adapting the PPID MoF to new media and social media. In the second semester of 2018, PPID MoF has utilized social media to educate the public about public information disclosure and the implementation of public information disclosure within the Ministry of Finance through Twitter (@PPIDKemenkeu), Instagram (ppid.kemenkeu), Facebook (@PPID.Keuangan), and Youtube (PPID Kementerian Keuangan).

The management of the PPID MoF social media is carried out in a professional manner, by continuing to follow the latest developments in its use. In preparing the material on social media, the PPID MoF social media admin has planned the material to be posted, so that it can be adjusted to the latest 
issues from the Ministry of Finance's social media, but still avoids repeating the material. Besides being used to educate the public, PPID social media is also used as a means to build the PPID MoF identity.

Henceforth, discussions related to this research will of course start from the opinions of previous communication experts. King (2009) calls this interactive strategy construction an "emerging communication strategy". He defines emerging communication strategies as communicative constructs derived from the interaction between reader / listener responses, existing contexts, and discursive patterns (King, 2009). Meanwhile, Murphy (2011) proposes that the strategic communication network view provides a "holistic view of the arena of opinion in which public communication takes place" and recognizes that it is interconnected, fluid, volatile and participatory in nature. Verhoeven, Zerfass, $\&$ Tench (2011) note that maintaining the social legitimacy of an organization is the main task of management communication.

The results of the communication strategy will be taken into consideration by the leadership to decide whether or not to carry out these recommendations. In line with Cornelissen's (2011) explanation which explains adaptive nature can encourage organizations to make strategy formation. Management decisions and input from employees will also affect the success or failure of implementing a communication strategy. After the decision was made regarding this matter, the recommendation that stated that it was necessary to build the PPID MoF identity through social media must be implemented by the Ministry of Finance's public information service officers. This of course will affect the work process or work culture of the organization.

The communication strategy used by the PPID MoF to build identity through social media needs to be done to reach the wider community, this is a form of implementation of the Law on Public Information Openness. The use of the hashtag \#temantranspparency is used as one of the methods used by the PPID MoF in campaigning for the PPID MoF identity to the public. This is in line with the social media mechanism where the use of hashtags can be in the form of narratives that are built to support brand awareness, the interaction process, and the identity of the PPID MoF as explained by Blaszka et al., (2012), Hambrick \& Pegoraro (2014), and Clark (2016).

In implementing the recommendations for the resulting communication strategy, the posts made by the PPID MoF admin were the result of discussions with the leadership. Since August 28 Year 2018, PPID MoF began campaigning for the public to participate in monitoring and become \#temantransparent. 
Thus, the social media activities carried out by the PPID MoF through the hashtag \#temantransparent prove that social media will quickly affect society and can use branding strategies like what Dickey \& Lewis (2010), Gallaugher \& Ransbotham (2010), and Kaplan \& Haenlein (2010).

To ensure that the PPID MoF identity development activities through the use of social media run effectively, organizational work culture has an important role in the successful implementation of these activities. In line with the characteristics of organizational culture described by Ojo (2010), organizational culture looks at the behavior of organizational members, firm rules, and organizational climate to see employee interactions, so the process of changing organizational work culture can be seen from the existence of new roles and additional tasks that are accepted and implemented by PDPSI Subdivision employees who are also the PPID MoF admin.

The schedule of uploading content made to support the PPID MoF work process is prepared as a guide for the PPID MoF social media admin in posting content. Each month a digital agenda is arranged for content to be uploaded in the following month. The content on the schedule may or may not change according to the results of the meeting and the determination of the strategic plan with the Chairman. This proves that there is a need for structures and systems for organization, as explained by Littlejohn et al (2017).

Some of the content to be posted is an implementation of the content theme produced through organizational decisions. Some of the themes in the monthly content that guide the social media admin can be seen in Table 1 . Schedule of PPID Ministry of Finance Updating Content in 2018, are as follows:

Table 1. Schedule of PPID Ministry of Finance Updating Content (Source: PPID, 2018)

\section{Figure Clarification}

1. Monday

1.1 Inspirational information. Contains inspirational information and activities within the scope of information disclosure of Public Bodies.

2. Tuesday

1.1 Activation. Contains information on the applicant's registration activation.

1.2 MoF Portfolio. Information about the duties and functions of the Ministry of Finance. 
Figure Clarification

3. Wednesday

1.1 Learning PPID. Used to provide more in-depth knowledge to the public on everything related to PPID.

4. Thursday

1.1 PPID stories. Contains story information from PPID MoF regarding the information disclosure process within the Ministry of Finance.

5. Friday

1.1 Worklife balance content. Focuses more on an emotional approach to work-life balance.

1.2 Simple information. Such as tips on protecting personal data, singleuse plastic diets, and more.

In the development of organizations and organizational culture, the themes of the content social media change to follows the organizational agenda setting. The themes are on Table 2. PPID Social Media Content Agenda in 2020, are as follows:

Table 2. PPID Social Media Content Agenda

(Source: PPID, 2020)

Figure Clarification

1. Monday

1.1 Education about PNBP. objectives, and types of PNBP. PPID requests from the Ministry of Finance are not subject to PNBP.

2. Tuesday

1.1 Education on EMAI and Illegal Cellphones.

1.2 News Kemenkeu PPID Coaching Clinic.

3. Wednesday

1.1 Education about ORI018.

4. Thursday

1.1 PEN program for MSMEs.

5. Friday

1.1 Ease of doing business achieved through tax breaks. 
The presence of the PPID MoF aims to be the main driver of public information disclosure in the field of state finance, to support Indonesia's inclusive economic growth in the 21st century (PPID MoF Vision). One of the efforts made to realize this vision is by utilizing the latest information and communication technology to support the management of public information disclosure, one of which is through social media. This is in line with the research of Tsimonis \& Dimitriadis (2014) that the use of social media is to build relationships with many people.

To support the PPID MoF identity development process through the use of social media, full commitment from the leadership is needed, supported by good implementation of public information service officers within the Ministry of Finance. The evaluation of the results of the use of social media resulted in the need for guidelines for the use of social media PPID Ministry of Finance for the PPID MoF admin. This was supported by the commencement of the drafting of these guidelines in the second semester of 2019, which is a year after the PPID MoF social media began.

It is hoped that the drafted guidelines can be used as a guide by the PPID admin of the Ministry of Finance in providing good and appropriate services through social media. Given the conditions of interest in order to achieve the goal of public information disclosure managed by PPID, as well as considering the effectiveness of communication that can be achieved through social media, PPID as a unit that manages public information services needs to build brand awareness and brand image, in forming brand trust. In essence, this will be relevant to make PPID MoF a trusted public information service. As the opinion of several previous experts regarding the importance of implementing corporate branding, branding communication, and brand awareness through social media (Dickey \& Lewis, 2010; Gallaugher \& Ransbotham, 2010; Kaplan \& Haenlein, 2010; Tsimonis \& Dimitriadis, 2014).

\section{CONCLUSION}

The construction of the PPID MoF identity which began at the end of 2018 went according to the planning that had been done. The process of developing an identity that begins with a communication strategy in determining the use of social media is considered to be one of the keys to building the identity of the PPID MoF. Identity development must be supported by infrastructure and human resources who are competent in their fields. This will have an 
effect on changing the work culture of the organization from initially passive to becoming more active in providing services or reaching the wider community. The PPID of the Ministry of Finance always seeks to provide an understanding of the importance of good state administration, namely one that is transparent, effective and efficient, accountable and accountable as mandated by Article 6 letter d of Law Number 14 of 2018 concerning Openness of Public Information. Improving the quality of public information services will of course encourage the achievement of the goal of public information disclosure managed by PPID. By considering the effectiveness of communication that can be achieved through social media, PPID as a unit that manages public information services needs to build a strong identity in forming brand trust. Recommendations for the next strategy are to utilize public relations practitioners/employees in the field of public information services to always innovate in supporting the PPID MoF identity development process on social media so that it will get better.

\section{ACKNOWLEDGEMENT}

I thank the following individuals for their expertise and assistance throughout all aspects of our study and for their help in writing the manuscript. This research was supported by [Mr. Benni Setiawan, Editor in Chief] and also the editorial team whose involved then provided insight and expertise that greatly assisted the research by the valuable suggestion and commentaries.

\section{REFERENCES}

Atkin, C. K., \& Rice, R. E. (2012). Advances in public communication campaigns. The International Encyclopedia of Media Studies.

Badea, M. (2014). Social media and organizational communication. ProcediaSocial and Behavioral Sciences, 149, 70-75. https://doi.org/10.1016/j. sbspro.2014.08.192

Bingöl, D., Lener, \., \& Çevik, E. (2013). The effect of organizational culture on organizational image and identity: Evidence from a pharmaceutical company. Procedia-Social and Behavioral Sciences, 99, 222-229. https://doi. org/10.1016/j.sbspro.2013.10.489

Blaszka, M., Burch, L. M., Frederick, E. L., Clavio, G., \& Walsh, P. (2012). \# WorldSeries: An empirical examination of a Twitter hashtag during a 
major sporting event. International Journal of Sport Communication, 5(4), $435-453$.

Cangara, H. (2013). Perencanaan dan strategi komunikasi. PT. Raja Grafindo Persada.

Christensen, L. T., \& Cornelissen, J. P. (2011). Corporate and organizational communication in conversation. Management Communication Quarterly, 25(3), 383-414.

Clark, R. (2016). "Hope in a hashtag": The discursive activism of\# WhyIStayed. Feminist Media Studies, 16(5), 788-804. https://doi.org/10.1080/146807 77.2016.1138235

Cornelissen, J. (2011). Corporate communication: A guide to theory and practice (3rd ed.). Sage.

Cornelissen, J. (2014). Corporate communication: A guide to theory and practice (4th ed.). Sage.

Dickey, I. J., \& Lewis, W. F. (2010). The evolution (revolution) of social media and social networking as a necessary topic in the marketing curriculum: a case for integrating social media into marketing classes. Advances in Marketing: Embracing Challenges and Change-A Global Perspective.

Finance, M. of. (2019a). Keputusan Menteri Keuangan Nomor 879/KMK.01/2019 tentang Penunjukan Atasan Pejabat Pengelola Informasi dan Dokumentasi Kementerian Keuangan, Atasan Pejabat Pengelola Informasi dan Dokumentasi Tingkat I, Pejabat Pengelola Informasi dan Dokumentasi Kementerian Keuangan. Jakarta.

Finance, M. of. (2019b). Peraturan Menteri Keuangan Nomor 129/PMK.01/2019 tentang Pedoman Layanan Informasi Publik Pejabat Pengelola Informasi dan Dokumentasi Kementerian Keuangan dan Perangkat Pejabat Pengelola Informasi dan Dokumentasi Kementerian Keuangan. PPID Kementerian Keuangan. Jakarta.

Flick, U. (2013). The SAGE handbook of qualitative data analysis. Sage.

Gallaugher, J., \& Ransbotham, S. (2010). Social media and customer dialog management at Starbucks. MIS Quarterly Executive, 9(4), 197-212.

Glynn, M. A., \& Navis, C. (2013). Categories, identities, and cultural classification: Moving beyond a model of categorical constraint. Journal of Management Studies, 50(6), 1124-1137. https://doi.org/10.1111/ joms.12023 
Hambrick, M. E., \& Pegoraro, A. (2014). Social Sochi: Using social network analysis to investigate electronic word-of-mouth transmitted through social media communities. International Journal of Sport Management and Marketing, 15(3-4), 120-140. 10.1504/IJSMM.2014.072005

He, H., \& Brown, A. D. (2013). Organizational identity and organizational identification: A review of the literature and suggestions for future research. Group Eु Organization Management, 38(1), 3-35. https://doi. org/10.1177/1059601112473815

Ibrahim, A. M., \& Tijjani, M. B. (2019). Adoption of information and communication technology to enhance verterinary pharmacology education in Nigerian universities. Informasi, 49(1), 51-63. https://doi. org/10.21831/informasi.v48i2.23348

Jati, W. R. (2016). Cyberspace, internet, dan ruang publik baru: Aktivisme online politik kelas menengah Indonesia. Jurnal Pemikiran Sosiologi, 3(1), 25-35. https://doi.org/10.22146/jps.v3i1.23524

Jensen, M., Kim, H., \& Kim, B. K. (2012). Meeting expectations: A role-theoretic perspective on reputation. The Oxford Handbook of Corporate Reputation, 140-159. DOI: 10.1093/oxfordhb/9780199596706.013.0007

Kaplan, A. M., \& Haenlein, M. (2010). Users of the world, unite! The challenges and opportunities of Social Media. Business Horizons, 53(1), 59-68. DOI: 10.1016/j.bushor.2009.09.003

Khopipah, S., \& Turistiati, A. T. (2019). Challenges of dual roles of marketing public relations and public relations in developing a positive image of PT. Overseas Zone. Informasi, 49(2), 91-100. https://doi.org/10.21831/ informasi.v49i2.28256

King, C. L. (2009). Emergent communication strategies. International Journal of Strategic Communication, 4(1), 19-38. https://doi. org/10.1080/15531180903415814

KLI, B. (2017). Survey kepuasan layanan informasi PPID 2017. In Laporan hasil survey kepuasan layanan informasi 2017.

Kreiss, D., Meadows, L., \& Remensperger, J. (2015). Political performance, boundary spaces, and active spectatorship: Media production at the 2012 Democratic National Convention. Journalism, 16(5), 577-595. https:// doi.org/10.1177/1464884914525562

Krippendorff, K. (2018). Content analysis: An introduction to its methodology. Sage 
Informasi, Vol. 51. No. 1. (2021), 1-26

publications.

Kusuma, Y. A. (2013). Analisis deskriptif pola manajemen dan karya seni rupa program residensi 'Transit\# 1' di Selasar Sunaryo Art Space. Universitas Pendidikan Indonesia.

Lindlof, T. R., \& Taylor, B. C. (2017). Qualitative communication research methods. Sage publications.

Littlejohn, S. W., Foss, K. A., \& Oetzel, J. G. (2017). Theories of human communication. 11th Editions. Waveland Press, Inc.

Lukaszewski, J. E. (2013). Lukaszewski on crisis communication: What your CEO needs to know about reputation risk and crisis management. Rothstein Publishing.

Macnamara, J. (2010). Public relations and the social: How practitioners are using, or abusing, social media. Asia Pacific Public Relations Journal, 11(1), $21-39$.

Macnamara, J., \& Zerfass, A. (2012). Social media communication in organizations: The challenges of balancing openness, strategy, and management. International Journal of Strategic Communication, 6(4), 287308. https://doi.org/10.1080/1553118X.2012.711402

Maier, C. T. (2016). Beyond branding: Van Riel and Fombrun's corporate communication theory in the human services sector. Qualitative Research Reports in Communication, 17(1), 27-35. https://doi.org/10.1080/174594 35.2015.1088892

Mujib, H. (2017). Organizational identity: an ambiguous concept in practical terms. Administrative Sciences, 7(3), 1-30. DOI:10.3390/admsci7030028

Murphy, P. (2011). Contextual distortion: Strategic communication vs. the networked nature of everything. International Communication Association 2011 Pre-Conference, 'Strategic Communication-A Concept at the Center of Applied Communications', Boston, MA.

Nasution, D. A. D. (2018). Analisis pengaruh SDM, insentif dan sarana pendukung terhadap implementasi SAP berbasis akrual pada Pemerintah Provinsi Sumatera Utara. Jurnal Akuntansi Bisnis Dan Publik, 9(1), 207218.

Naughton, J. (2012). What you really need to know about the internet. From Gutenberg to Zuckerberg. Quercus

Nguru, M. N., \& Ibrahim, A. M. (2018). Public relations and employee 
performance in Nigerian institution of higher learning. Informasi. 48(2), 267-279. https://doi.org/10.21831/informasi.v48i2.21972

Octavianto, A. W. (2014). Strukturasi Giddens dan social construction of technology (SCoT) sebagai pisau analisis alternatif penelitian sosial atas teknologi media baru. Ultimacomm: Jurnal Ilmu Komunikasi, 6(2), 41-57.

Ojo, O. (2010). Organisational culture and corporate performance: Empirical evidence from Nigeria. Journal of Law and Governance, 5(2), 1-12. https:// doi.org/10.15209/jbsge.v5i2.180

Olivant, S. (2016). Keeping shtum and other communication strategies. CreateSpace

Paolella, L., \& Durand, R. (2016). Category spanning, evaluation, and performance: Revised theory and test on the corporate law market. Academy of Management Journal, 59(1), 330-351. https://doi.org/10.5465/ amj.2013.0651

Perdana, R. P., Christin, M., \& Malau, R. M. U. (2016). Citra kawasan strategis nasional cekungan Bandung melalui instagram pada pengguna hashtag\# explorebandung. Jurnal Kajian Komunikasi, 4(2), 185-198. https://doi. org/10.24198/jkk.v4i2.7951

Plowman, K. D. (2013). Creating a model to measure relationships: US Army strategic communication. Public Relations Review, 39(5), 549-557. DOI: 10.1016/j.pubrev.2013.07.001

Plowman, K. D. (2016). Big strategy to little strategy: A multiple case analysis of public affairs planning. Journal of Public Affairs, 17(3), 1-9. https://doi. org/10.1002/pa.1627

Plowman, K. D., \& Wilson, C. (2018). Strategy and tactics in strategic communication: Examining their intersection with social media use. International Journal of Strategic Communication, 12(2), 125-144. https:// doi.org/10.1080/1553118X.2018.1428979

PPID, M. of F. (2018). Panduan media sosial PPID Kementerian Keuangan.

PPID, M. of F. (2020). PPID Social Media content agenda.

Prasetyo, Y. W., \& Himam, F. (2013). Pengembangan Identitas Organisasi sebagai Strategi Bisnis. Jurnal Psikologi, 40(2), 226-239. DOI: 10.22146/ jpsi.6979

Putra, N. A. (2017). Literasi media sosial humas pemerintah daerah. Informasi. 47(2), 271-284. https://doi.org/10.21831/informasi.v47i2.17235

Rahmawati, R., \& others. (2011). Efektivitas E-service di pemerintah daerah. 
Informasi, Vol. 51. No. 1. (2021), 1-26

Simposium Nasional Otonomi Daerah 2011.

Saunders, M., Lewis, P., \& Thornhill, A. (2016). Research methods for business students Seventh Edition. Pearson Education Limited.

Schein, E. H. (2010). Organizational Culture and Leadership, 4th Edn San Francisco. Jossey-Bass.

Smith, R. D. (2013). Strategic planning for public relations. Routledge.

Sriwijayanti, H. (2019). Analisis pengaruh transparansi, akuntabilitas dan pemanfaatan sistem informasi akuntansi keuangan daerah terhadap pengelolaan APBD (Studi persepsi pengelola APBD SKPD Dinas Pemerintah Kota Padang). Jurnal Ekobistek, 7(1), 89-101.

Sweetser, K. D., \& Kelleher, T. (2011). A survey of social media use, motivation and leadership among public relations practitioners. Public Relations Review, 37(4), 425-428. DOI:10.1016/j.pubrev.2011.08.010

Tench, R., \& Yeomans, L. (2017). Exploring public relations: global strategic communication. Pearson Higher Ed.

Theaker, A. (2016). The public relations handbook. Routledge.

Trisnawati, N. N., \& Wiratmaja, D. N. (2018). Pengaruh kualitas sumber daya manusia dan sistem pengendalian intern pada kualitas laporan keuangan pemerintah daerah. E-Jurnal Akuntansi, 24(1), 768-792. https://doi. org/10.24843/EJA.2018.v24.i01.p29

Tsimonis, G., \& Dimitriadis, S. (2014). Brand strategies in social media. Marketing Intelligence Ef Planning, 32(3), 328-344. https://doi.org/10.1108/MIP-042013-0056

Uzunoglu, E., \& Onat, F. (2012). Public relations in a time of turbulence: A study on Turkish PR firms. Journal of Human Sciences, 9(1), 769-792.

van Ruler, B. (2018). Communication theory: An underrated pillar on which strategic communication rests. International Journal of Strategic Communication, 12(4), 367-381. https://doi.org/10.1080/155311 8X.2018.1452240

Verhoeven, P., Zerfass, A., \& Tench, R. (2011). Strategic orientation of communication professionals in Europe. International Journal of Strategic Communication, 5(2), 95-117. https://doi.org/10.1080/155311 8X.2011.561080.

Werder, K. P. (2015). The integration of domains: Multidisciplinary approaches to strategic communication campaigns. International Journal 
The implication of organizational culture ... (Reinaldy Ferdiansyah, Andre Noevi Rahmanto, and Yulius Slamet)

of Strategic Communication, 9(2), 79-86. https://doi.org/10.1080/15531 18X.2015.1010829

Wright, D. K., \& Hinson, M. D. (2015). Examining social and emerging media use in public relations practice: A ten-year longitudinal analysis. Public Relations Journal, 9(2), 1-26.

Yin, R. K. (2018). Case study research and applications. Sage. 
Informasi, Vol. 51. No. 1. (2021), 1-26 